\title{
Obtaining Plasticized Starch and Microfibrillated Cellulose from Oil Palm Empty Fruit Bunches: Preparation and Properties of the Pure Materials and Their Composites
}

\author{
Valérya C. Teles, ${ }^{\text {a }}$ Mariana Roldi, ${ }^{\mathrm{b}}$ Sandra M. Luz, ${ }^{\mathrm{b}}$ Wellington R. Santos, ${ }^{\mathrm{a}}$ \\ Larissa Andreani, ${ }^{\mathrm{a}}$ and Leonardo. F. Valadares ${ }^{\mathrm{a}, *}$ \\ Starch and celluloses are biodegradable resources of great importance in \\ terms of marketing. These biopolymers can be used to generate films with \\ interesting mechanical, optical, and thermal properties, which can \\ substitute for plastic films in certain applications, e.g., packaging materials. \\ This study describes the preparation of pure plasticized starch films, \\ prepared from soluble starch and glycerol, and the preparation of \\ microfibrillated cellulose films from oil palm empty fruit bunches fabricated \\ via casting. Composites made of plasticized starch were also prepared \\ with microfibrillated cellulose added in $10 \%$ increments. The density, color \\ difference, opacity, morphology, water activity, water affinity, and thermal \\ and mechanical characteristics of the films were investigated. Plasticized \\ starch is a translucent material with contact transparency; it is fragile and \\ has relatively high water and glycerol contents. The thermogravimetric \\ analysis of materials displayed up to four stages of weight loss related to \\ water evaporation, glycerol, starch, and cellulose thermal degradation. As \\ a consequence, the materials with higher cellulose content exhibited better \\ thermal resistance. The composites with $90 \%$ of microfibrillated cellulose \\ resulted in increased tensile strength when compared to the pure \\ materials. The pure microfibrillated cellulose presented the highest values \\ of Young modulus. The addition of plasticized starch to microfibrillated \\ cellulose improved the maximum strain of the composites.
}

Keywords: Plasticized starch films; Microfibrillated cellulose; Oil palm empty fruit bunches; Mechanical and thermal properties

Contact information: a: Embrapa Agroenergia, Parque Estação Biológica S/N, Av. W3 Norte (final), Brasília, DF 70770-901 Brazil; b: Gama Campus, Universidade de Brasília, Área Especial de Indústria Projeção A Setor Leste Gama, Brasilia, DF 72444-240 Brazil;

* Corresponding author: leonardo.valadares@embrapa.br

\section{INTRODUCTION}

The substitution of petroleum-based plastics with biodegradable materials is of considerable research interest due to growing environmental concerns. Currently, petrochemical plastics offer low production costs while providing excellent properties and are widely used. However, synthetic plastics do not degrade in the environment, which leads to a high degree of pollution, particularly in the oceans. However, renewable biodegradable materials usually have water affinity, low plasticity, and require higher production costs; therefore, they are not cost-competitive (Chen and Jiang 2018).

Strong public policy formation and sweeping cultural changes are imperative for the widespread adoption of biodegradable plastics. It is also necessary to reduce the costs 
of renewable materials and to develop biodegradable materials with attractive properties (Ilyas et al. 2019). However, the production of low-cost biodegradable materials with plastic properties and water resistance remains a challenge.

Carbohydrate compounds obtained from plants are an abundant bioresource used to fabricate biodegradable materials on the industrial scale. For example, cellulose is the most abundant organic polymer on Earth, and it constitutes a major fraction of the dried biomass obtained from plants (Tan et al. 2019). The process of cellulose purification, although costly, is currently used in industrial settings and provides several biodegradable and compostable commercial products.

This research group deals with the pulp extracted from oil palm empty fruit bunches (OPEFB) (Fiorote et al. 2019), an agri-industrial residue from the production of palm oil. Oil palm fibers can be used for the elaboration of biodegradable materials, as demonstrated by multiple studies (Fahma et al. 2010; Campos et al. 2017; Ramlee et al. 2019). When high shear is applied to the pulp, the cellulose undergoes a microfibrillation process that involves breaking and defibrillating the material via mechanical action.

The microfibrillation process increases the surface area of cellulose, and depending on the intensity, it can generate fibers with nanometer thickness, high aspect ratios, and network structures containing crystalline and amorphous regions (Lavoine et al. 2012; Hiltunen et al. 2018). The higher surface area of microfibrillated cellulose (MFC) allows strong interfacial adhesion with polymers matrices, making it a versatile material for preparing composites (Iwamoto et al. 2008).

Starch is also a biodegradable polymer of immense importance for human consumption and animal feed that consists primarily of the linear polymer amylose and the highly branched polymer amylopectin (Karim et al. 2000). Although it is possible to produce starch films, they are often brittle and have no thermoplastic characteristics, thus limiting their potential uses (Li et al. 2018). Low molecular weight additives, known as plasticizers, are therefore usually added to starch to increase the space between the chains of this semicrystalline polymer, resulting in a matrix with thermoplastic behavior, which greatly facilitates its usage in industrial processing. Several polyols have been investigated as plasticizers in the manufacture of thermoplastic starch (Schmitt et al. 2015). Glycerol is a promising polyol among those examined since it is a by-product of biodiesel production, and as such, is an abundant and inexpensive plasticizer (Abbott et al. 2014).

Adhesion between gelatinized starch and cellulose is mediated by water, which has been described in scientific literature and applied in various industries (Liu et al. 2017). Strong adhesion originates upon the evaporation of water; the polymer chains come in contact due to capillary adhesion and remains bonded due to van der Waals forces at the interface.

This study presents the preparation of composites formulated with starch, glycerol, and microfibrillated oil palm cellulose. The effect of the cellulose content on the properties of the resulting materials, with a wide range of compositions, ranging from pure plasticized starch (PS) to pure MFC, were identified. To this end, 11 film formulations were prepared using increments of $10 \%$ cellulose in the material compositions. The optical, thermal, mechanical, and water affinity properties were investigated. Therefore, this study provides a decisive tool for the formulations of starch and cellulose composites that can be employed to identify potential applications. 


\section{EXPERIMENTAL}

\section{Materials}

The oil palm empty fruit bunches (OPEFB) (cultivar 2301, Tenera) was supplied by Embrapa Cerrados (Planaltina, DF, Brazil). The sodium chlorite (Sigma-Aldrich, St. Louis, MO), glacial acetic acid (Dinâmica, São Paulo, Brazil), potassium hydroxide (Vetec, Sigma-Aldrich, St. Louis, MO), and glycerol (Vetec) were used as received. The soluble corn starch (Vetec) was dried in an oven $\left(70{ }^{\circ} \mathrm{C}\right.$ for $\left.3 \mathrm{~h}\right)$ prior the use.

\section{Preparation of the MFC}

The OPEFB was autoclaved $\left(127{ }^{\circ} \mathrm{C}\right.$ for $\left.30 \mathrm{~min}\right)$, threshed, oven-dried $\left(65^{\circ} \mathrm{C}\right.$ for $24 \mathrm{~h}$ ), and ground in a Willey mill (Fortinox, Piracicaba, Brazil). The purified cellulose was obtained following a delignification/bleaching treatment described by Fiorote et al. (2019). Briefly, a sequence of extractions was conducted on the ground OPEFB: (1) extraction with ethanol and petroleum ether; (2) extraction with aqueous sodium chlorite; and (3) extraction with an aqueous $\mathrm{KOH}$ solution. The fibers were washed with water between each extraction. The purified cellulose was sheared in an aqueous medium (2.6 wt\%) using a IKA Ultra-Turrax disperser (Staufen, Germany) to produce the MFC. The final MFC product was obtained after 12 cycles of 10 min shearing at $24000 \mathrm{rpm}$.

\section{Preparation of the Plasticized Starch (PS), MFC, and Composite Films}

The PS, MFC, and composite films were prepared via a dispersion casting/ evaporation process. First, $500 \mathrm{~g}$ of starch/glycerol solution was prepared, constituting of a $4.0 \%$ soluble starch homogenized in $93.5 \%$ distilled water via mechanical agitation for $30 \mathrm{~min}$. The resulting solution was gelatinized upon heating with constant stirring in a water bath $\left(70{ }^{\circ} \mathrm{C}\right)$. Next, $2.5 \mathrm{wt} \%$ glycerol was added, and the solution was maintained at $70^{\circ} \mathrm{C}$ while being stirred for an additional $15 \mathrm{~min}$. In addition to the pure PS and pure MFC films, the following formulations of PS/MFC composites were prepared: 90/10, 80/20, $70 / 30,60 / 40,50 / 50,40 / 60,30 / 70,20 / 80$, and 10/90. For the composites, aqueous MFC was added to the PS solution and stirred for $15 \mathrm{~min}$. After sonicating for $10 \mathrm{~min}, 30 \mathrm{~g}$ of the resulting dispersions were poured into polystyrene Petri dishes $(135 \mathrm{~mm})$ and dried in a force air flow oven at $30{ }^{\circ} \mathrm{C}$ for $24 \mathrm{~h}$.

\section{Characterizations}

Film thickness and density

The density was determined according to the methodology presented by Müller et al. (2008). First, phosphorus pentoxide was placed in a desiccator in order to attain a relative humidity $(\mathrm{RH})$ of $0 \%$. Three specimens $(20 \mathrm{~mm} \times 20 \mathrm{~mm})$ of each formulation were stored in the desiccator for 20 days at $23{ }^{\circ} \mathrm{C}$. Afterward, the specimens were weighed and the thickness was measured at five random points using a digital external micrometer (Digimess, model IP54, São Paulo, Brazil). The density was calculated using Eq. 1,

$$
d=w /(A \cdot t)
$$

where $d$ is the dry density of the sample $\left(\mathrm{g} \cdot \mathrm{cm}^{-3}\right), w$ is the specimen dry weight $(\mathrm{g}), A$ is the sample area $\left(\mathrm{cm}^{2}\right)$, and $t$ is the film thickness $(\mathrm{cm})$. 


\section{Moisture content and water activity}

The moisture content was determined gravimetrically according to ASTM standard D644-99 (2007). Each formulation was oven-dried (105 ${ }^{\circ} \mathrm{C}$ for $\left.24 \mathrm{~h}\right)$ in triplicate, and the moisture content was calculated as the difference between the initial and final weight of the samples.

The water activity $\left(a_{\mathrm{w}}\right)$ measurements were performed in triplicate. Samples were conditioned at $50 \% \mathrm{RH}$ at $23{ }^{\circ} \mathrm{C}$ for at least $72 \mathrm{~h}$ before each measurement. The films were cut and the water activity measurements were performed with an AquaLab instrument (Decagon, model 4TEV, Munich, Germany) after being calibrated with pure water $\left(a_{\mathrm{w}}=\right.$ $1.000 \% \pm 0.003 \%)$ and a $0.50 \mathrm{~mol} \cdot \mathrm{kg}^{-1} \mathrm{KCl}$ solution $\left(a_{\mathrm{w}}=0.984 \% \pm 0.003 \%\right)$.

\section{Color difference and opacity}

The renewable films were oven-dried $\left(30{ }^{\circ} \mathrm{C}\right.$ for $\left.4 \mathrm{~h}\right)$ and analyzed in triplicate with a Konica Minolta colorimeter (model CR-400, Tokyo, Japan) in reflectance mode using the CIEL*a*b* classification system and illuminant D65. The color difference was calculated according to Eq. 2,

$$
\Delta E^{*}=\sqrt{\left(L^{*}-L_{0}^{*}\right)^{2}+\left(a^{*}-a_{0}^{*}\right)^{2}+\left(b^{*}-b_{0}^{*}\right)^{2}}
$$

where $\Delta E^{*}$ is the color difference, $L^{*}$ is the luminosity of the sample, $\mathrm{L}_{0} *$ is the luminosity of the standard, $a^{*}$ and $b^{*}$ are the color parameters of the sample, and $a 0^{*}$ and $b_{0}{ }^{*}$ are the color parameters of the standard (HunterLab 1996; HunterLab 2008). The opacity was calculated according to Eq. 3,

$$
Y=\left(Y_{b l} / Y_{w h}\right) \times 100
$$

where $Y$ refers to the opacity of the sample, $Y_{b l}$ is the luminosity measured with the sample over a black support, and $Y_{w h}$ is the luminosity measured over a white support (HunterLab 1996; HunterLab 2008). The instrument was calibrated with a standard white reference plate provided by Konica Minolta, and for the calculation of $\Delta E^{*}$, a polyethylene film was used as the standard $\left(L_{0}{ }^{*}=89.63, a 0^{*}=0.26\right.$, and $\left.b_{0}{ }^{*}=-2.53\right)$. The opacity measurements were performed using white and black supports.

\section{Morphology}

The MFC morphology was analyzed via transmission electron microscopy (TEM). The MFC aqueous dispersion was diluted, sonicated, and sedimented within 5 min. A drop of the aqueous dispersion was deposited on a microscope grid and allowed to dry. The TEM images were obtained with a Carl Zeiss microscope (model 109, Jena, Germany) at $80 \mathrm{kV}$.

The surface morphology of the PS, MFC, and their composites films were evaluated via field-emission scanning electron microscopy (SEM) using a Zeiss microscope (model Sigma HV, Cambridge, UK). Prior to analysis, the specimens were coated with gold via sputtering (model Q150T-ES, Quorum Technologies, Lewes, UK). ImageJ 1.53a software (NIH, Bethesda, MD) was used to evaluate the distribution of fiber thickness. 


\section{Thermal analysis}

Thermogravimetric analysis (TGA) and differential scanning calorimetry (DSC) were performed to evaluate the thermal stability and to determine the differences in thermal transitions of the PS/MFC formulations, respectively, using a Simultaneous TGA/DSC SDT Q600 instrument (TA Instruments, New Castle, DE). The samples (10 mg to $15 \mathrm{mg}$ ) were analyzed in alumina pans at a heating rate of $10^{\circ} \mathrm{C} \cdot \mathrm{min}^{-1}$ from $25^{\circ} \mathrm{C}$ to $600{ }^{\circ} \mathrm{C}$ under a flow of nitrogen $\left(100 \mathrm{~mL} \cdot \mathrm{min}^{-1}\right)$. Sapphire was used as the internal reference for the DSC analysis.

\section{Mechanical properties}

The Young modulus, tensile strength, and maximum strain of the PS/MFC renewable films were determined using an Arotec universal testing machine (model WDW20E, Beijing, China). A 50-kgf load cell was used at a crosshead speed of $1.0 \mathrm{~mm} \cdot \mathrm{min}^{-1}$ and with an initial grip separation of $25 \mathrm{~mm}$. The test specimens (type $\mathrm{V}$ dimensions following the ASTM D638-02 (2002) guidelines) were conditioned at $23{ }^{\circ} \mathrm{C}$ and $50 \% \mathrm{RH}$ prior to analysis. At least five specimens were used for each sample formulation to determine the mean and standard deviation. Tukey's test was used to compare the means with a confidence level of $95 \%$.

\section{RESULTS AND DISCUSSION}

The procedure used herein generated the PS and MFC films, as well as their composite films with a wide range of compositions. The thicknesses of the starch/MFC films ranged from $0.063 \mathrm{~mm}$ to $0.122 \mathrm{~mm}$. In general, the formulations containing a higher concentration of MFC resulted in thinner films. Film characterization data, i.e., density, water content and activity, color difference, and opacity, are shown in Table 1.

The density ranged between 1.336 and $1.621 \mathrm{~g} / \mathrm{cm}^{3}$; all the values were found to be statistically similar using Tukey's procedure with $95 \%$ confidence limits. These results indicated that the casting technique employed to fabricate the films consistently provided homogeneous films of similar thickness, which is desirable for various applications.

Regarding the moisture content of the films, it was observed that when more MFC was present in the formulation, the composites possessed lower moisture contents, therefore suggesting that MFC contributed to the acquisition of less hygroscopic materials. However, the individual moisture content values did not elucidate the nature of the water attachment, i.e., whether it was bound, free, inert, or occluded (Yoshida et al. 1993), although it is an important factor to consider since it can influence the susceptibility of a material toward deterioration, and thus have a profound effect on product shelf life.

To enhance the shelf life of a material, biochemical reactions and microbial growth must be avoided, which are largely inhibited in materials with low $a_{\mathrm{w}}$. Reducing the amount of free water in a formulation means that less water is available, which minimizes microorganism growth as well as undesirable biochemical reactions. Products with an $a_{\mathrm{w}}$ value less than 0.600 are relatively protected against microbial contamination, whereas the proliferation of specific microorganisms can occur with an $a_{\mathrm{w}}$ value greater than 0.600 (Mathlouthi 2001). 
Table 1. Characterization of the PS, MFC, and PS/MFC Composite Films

\begin{tabular}{|c|c|c|c|c|c|c|c|}
\hline $\begin{array}{c}\text { PS/MFC } \\
\text { Composite } \\
\text { Composition } \\
\text { (g/g) }\end{array}$ & $\begin{array}{c}\text { Film } \\
\text { Thickness } \\
(\mathrm{mm})\end{array}$ & $\begin{array}{l}\text { Density } \\
\left(\mathrm{g} / \mathrm{cm}^{3}\right)\end{array}$ & $\begin{array}{c}\text { Water } \\
\text { Content } \\
(\%)\end{array}$ & $\begin{array}{l}\text { Water } \\
\text { Activity } \\
\text { (aw) After } \\
\text { Drying }\end{array}$ & $\begin{array}{c}\text { Water } \\
\text { Activity } \\
\left(\mathrm{aw}_{w}\right) 23 \\
{ }^{\circ} \mathrm{C} \mathrm{RH} \text { : } \\
50 \%\end{array}$ & $\begin{array}{c}\text { Color } \\
\text { Difference }\end{array}$ & $\begin{array}{c}\text { Opacity } \\
(\%)\end{array}$ \\
\hline $100 / 0$ & $\begin{array}{c}0.108 \pm \\
0.023\end{array}$ & $\begin{array}{c}1.411 \pm \\
0.160\end{array}$ & $\begin{array}{r}39.047 \\
\pm 1.673\end{array}$ & $\begin{array}{c}0.295 \pm \\
0.001\end{array}$ & $\begin{array}{c}0.784 \pm \\
0.001\end{array}$ & $\begin{array}{c}0.553 \pm \\
0.025\end{array}$ & $\begin{array}{c}15.203 \pm \\
0.456\end{array}$ \\
\hline $90 / 10$ & $\begin{array}{c}0.107 \pm \\
0.014\end{array}$ & $\begin{array}{c}1.621 \pm \\
0.145\end{array}$ & $\begin{array}{r}36.325 \\
\pm 0.559\end{array}$ & $\begin{array}{c}0.303 \pm \\
0.002\end{array}$ & $\begin{array}{c}0.781 \pm \\
0.001\end{array}$ & $\begin{array}{c}5.735 \pm \\
0.426\end{array}$ & $\begin{array}{c}18.641 \pm \\
0.107\end{array}$ \\
\hline $80 / 20$ & $\begin{array}{c}0.122 \pm \\
0.026\end{array}$ & $\begin{array}{c}1.472 \pm \\
0.321\end{array}$ & $\begin{array}{r}30.863 \\
\pm 0.867\end{array}$ & $\begin{array}{c}0.319 \pm \\
0.002\end{array}$ & $\begin{array}{c}0.779 \pm \\
0.001\end{array}$ & $\begin{array}{c}11.386 \pm \\
1.446\end{array}$ & $\begin{array}{r}20.246 \pm \\
1.116\end{array}$ \\
\hline $70 / 30$ & $\begin{array}{c}0.113 \pm \\
0.024\end{array}$ & $\begin{array}{c}1.545 \pm \\
0.049\end{array}$ & $\begin{array}{r}29.282 \\
\pm 0.210 \\
\end{array}$ & $\begin{array}{c}0.325 \pm \\
0.001\end{array}$ & $\begin{array}{c}0.787 \pm \\
0.001\end{array}$ & $\begin{array}{c}10.969 \pm \\
0.995\end{array}$ & $\begin{array}{c}21.622 \pm \\
0.683\end{array}$ \\
\hline $60 / 40$ & $\begin{array}{c}0.107 \pm \\
0.023\end{array}$ & $\begin{array}{c}1.477 \pm \\
0.281\end{array}$ & $\begin{array}{r}24.972 \\
\pm 1.157\end{array}$ & $\begin{array}{c}0.423 \pm \\
0.001\end{array}$ & $\begin{array}{c}0.777 \pm \\
0.002\end{array}$ & $\begin{array}{c}14.716 \pm \\
1.350\end{array}$ & $\begin{array}{c}26.112 \pm \\
2.111\end{array}$ \\
\hline $50 / 50$ & $\begin{array}{c}0.089 \pm \\
0.021\end{array}$ & $\begin{array}{c}1.410 \pm \\
0.304\end{array}$ & $\begin{array}{l}20.871 \\
\pm 0.611\end{array}$ & $\begin{array}{c}0.343 \pm \\
0.000\end{array}$ & $\begin{array}{c}0.771 \pm \\
0.002\end{array}$ & $\begin{array}{c}15.799 \pm \\
1.035\end{array}$ & $\begin{array}{c}27.799 \pm \\
1.323\end{array}$ \\
\hline $40 / 60$ & $\begin{array}{c}0.082 \pm \\
0.019\end{array}$ & $\begin{array}{c}1.360 \pm \\
0.272\end{array}$ & $\begin{array}{r}17.858 \\
\pm 0.998\end{array}$ & $\begin{array}{c}0.347 \pm \\
0.001\end{array}$ & $\begin{array}{c}0.772 \pm \\
0.001\end{array}$ & $\begin{array}{c}14.368 \pm \\
0.454\end{array}$ & $\begin{array}{r}39.489 \pm \\
4.826\end{array}$ \\
\hline $30 / 70$ & $\begin{array}{c}0.063 \pm \\
0.011\end{array}$ & $\begin{array}{c}1.411 \pm \\
0.072\end{array}$ & $\begin{array}{r}13.357 \\
\pm 0.686\end{array}$ & $\begin{array}{c}0.362 \pm \\
0.001\end{array}$ & $\begin{array}{c}0.757 \pm \\
0.002\end{array}$ & $\begin{array}{c}24.065 \pm \\
1.153\end{array}$ & $\begin{array}{r}49.195 \pm \\
1.014\end{array}$ \\
\hline $20 / 80$ & $\begin{array}{c}0.069 \pm \\
0.018\end{array}$ & $\begin{array}{c}1.433 \pm \\
0.076\end{array}$ & $\begin{array}{r}11.744 \\
\pm 0.540\end{array}$ & $\begin{array}{c}0.371 \pm \\
0.001\end{array}$ & $\begin{array}{c}0.730 \pm \\
0.001\end{array}$ & $\begin{array}{c}10.565 \pm \\
0.240\end{array}$ & $\begin{array}{c}40.936 \pm \\
1.475\end{array}$ \\
\hline $10 / 90$ & $\begin{array}{c}0.073 \pm \\
0.024\end{array}$ & $\begin{array}{c}1.398 \pm \\
0.445\end{array}$ & $\begin{array}{r}11.107 \\
\pm 0.638\end{array}$ & $\begin{array}{c}0.365 \pm \\
0.004\end{array}$ & $\begin{array}{c}0.697 \pm \\
0.002\end{array}$ & $\begin{array}{c}15.767 \pm \\
0.994\end{array}$ & $\begin{array}{r}42.869 \pm \\
1.432\end{array}$ \\
\hline $0 / 100$ & $\begin{array}{c}0.072 \pm \\
0.017\end{array}$ & $\begin{array}{c}1.336 \pm \\
0.147\end{array}$ & $\begin{array}{c}9.775 \pm \\
0.251\end{array}$ & $\begin{array}{c}0.345 \pm \\
0.002\end{array}$ & $\begin{array}{c}0.726 \pm \\
0.004\end{array}$ & $\begin{array}{c}15.753 \pm \\
1.205\end{array}$ & $\begin{array}{r}76.685 \pm \\
3.676\end{array}$ \\
\hline
\end{tabular}

The dried PS/MFC composites exhibited $a_{\mathrm{w}}$ values of 0.295 to 0.423 (Table 1), suggesting that these dry materials provided good microbial resistance. Nevertheless, remarkable differences were observed in the water activity values of composites conditioned at a temperature of $23{ }^{\circ} \mathrm{C}$ and a $\mathrm{RH}$ of $50 \%$, and the dried samples, which was largely due to the hygroscopicity of the formulations. The previously conditioned materials showed $a_{\mathrm{w}}$ values of 0.697 to 0.787 , identifying them as intermediate moisture products, which indicated a susceptibility to microbial growth and biochemical reactions (VeigaSantos $e t$ al. 2005). There were no noticeable differences in water activity among the tested formulations, which indicated that the degree of MFC content in the composites had no effect on increasing the shelf life of starch composites.

Regarding the color difference of the composites, the addition of cellulose generally contributed to increased color variation, which increased with an increasing MFC content. Pure PS has a low opacity, i.e., it is translucent, whereas pure MFC is very opaque. Among the composites, the addition of cellulose to the PS matrix increased the opacity of the films.

The morphology of MFC from OPEFB was previously described by Fiorote $e t$ al. (2019). Figure 1 shows the MFC TEM images obtained from the colloidal fraction of MFC. The figure shows fibers that ranged in thickness from $10 \mathrm{~nm}$ to $200 \mathrm{~nm}$, with all the thinner nanostructures connected to thicker fibers. The thicker fibers were not sectioned, and their extremities exhibited microfibril structures that formed during the shear process, when using the disperser. 

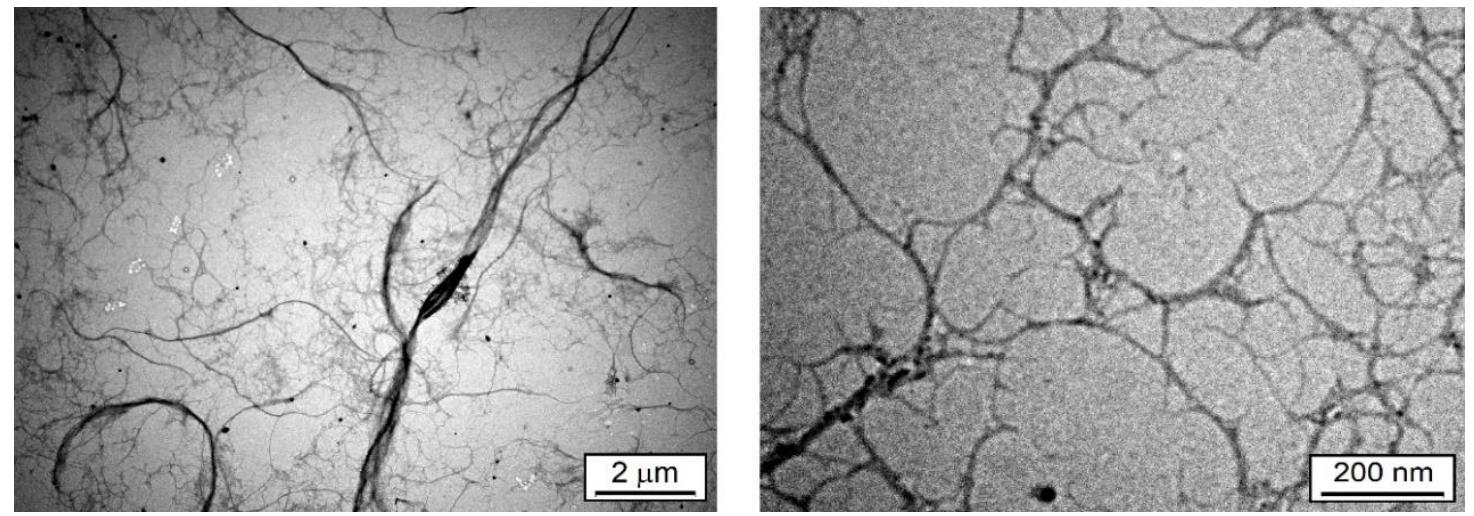

Fig. 1. The TEM images of MFC, in which it is possible to observe the interconnected fibrillar nanostructures

The SEM images (Fig. 2) show the top surfaces of the representative films. The pure PS film (Fig. 2a) was very flat at the micrometer level, although small cracks were present on the surface. These cracks indicated the brittle nature of the starch film, even when using glycerol as a plasticizer. Fibers can be observed on the surface of all the composite compositions as well as on the pure MFC sample. The similarity in the starch and cellulose chemical structures resulted in good surface bonding (Ilyas et al. 2018), as indicated by the continuous matrices shown in Fig. 2b and Fig. 2c.
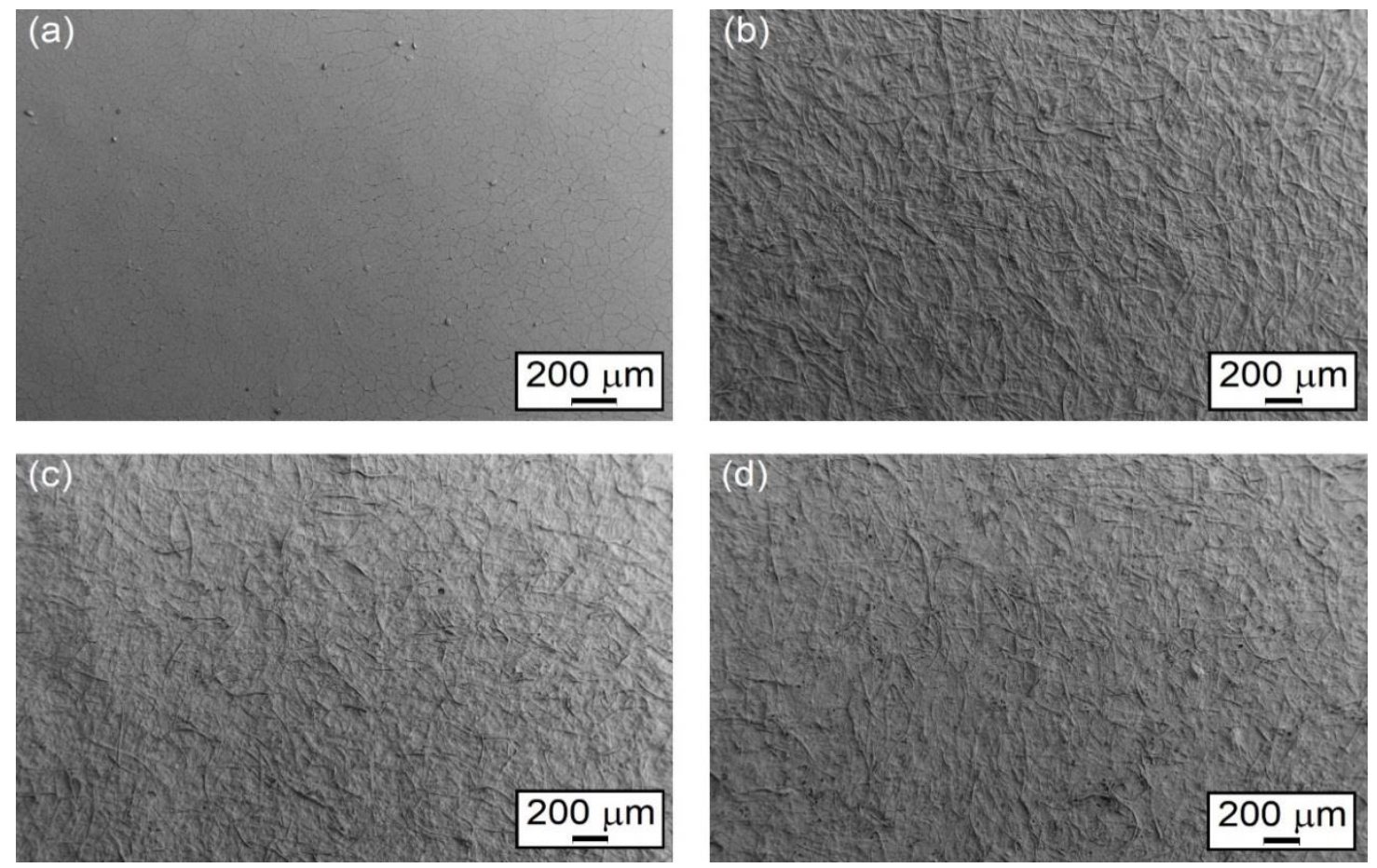

Fig. 2. The SEM surface images of (a) pure PS, (b) PS/MFC 70/30 composite, (c) PS/MFC 30/70 composite, and (d) pure MFC films

All composite formulations (micrographs not shown) displayed similar matrices with evidence of good interfacial adhesion. Previous studies by Liu et al. (2010) and Cheng et al. (2019) found differences in starch and cellulose nanocomposites as the cellulose content was increased, possibly due to a decrease in the number of glycerol molecules per 
existing nanofiber. This effect from a reduced glycerol/MFC ratio was not observed in this work, since the percentages of MFC used in the nanocomposite formulations were much higher than those in the previous studies, making any effect by the glycerol content imperceptible. The compact surface of the pure MFC film was likely due to the presence of thin fibers filling the space between the thicker fibers (as shown in Fig. 1d) (Lengowski et al. 2020; Tozluoglu et al. 2021). The fibers at the surface of the films had an average thickness of $13.5 \mu \mathrm{m} \pm 4.6 \mu \mathrm{m}$, as measured and averaged for 100 particles in Fig. $2 \mathrm{~d}$.

Figure 3 displays the thermogravimetric curves and derivative thermogravimetric curves (DTG) of the PS, MFC, and PS/MFC composite samples. The DTG curves make it possible to identify the temperature at which weight loss is most apparent.
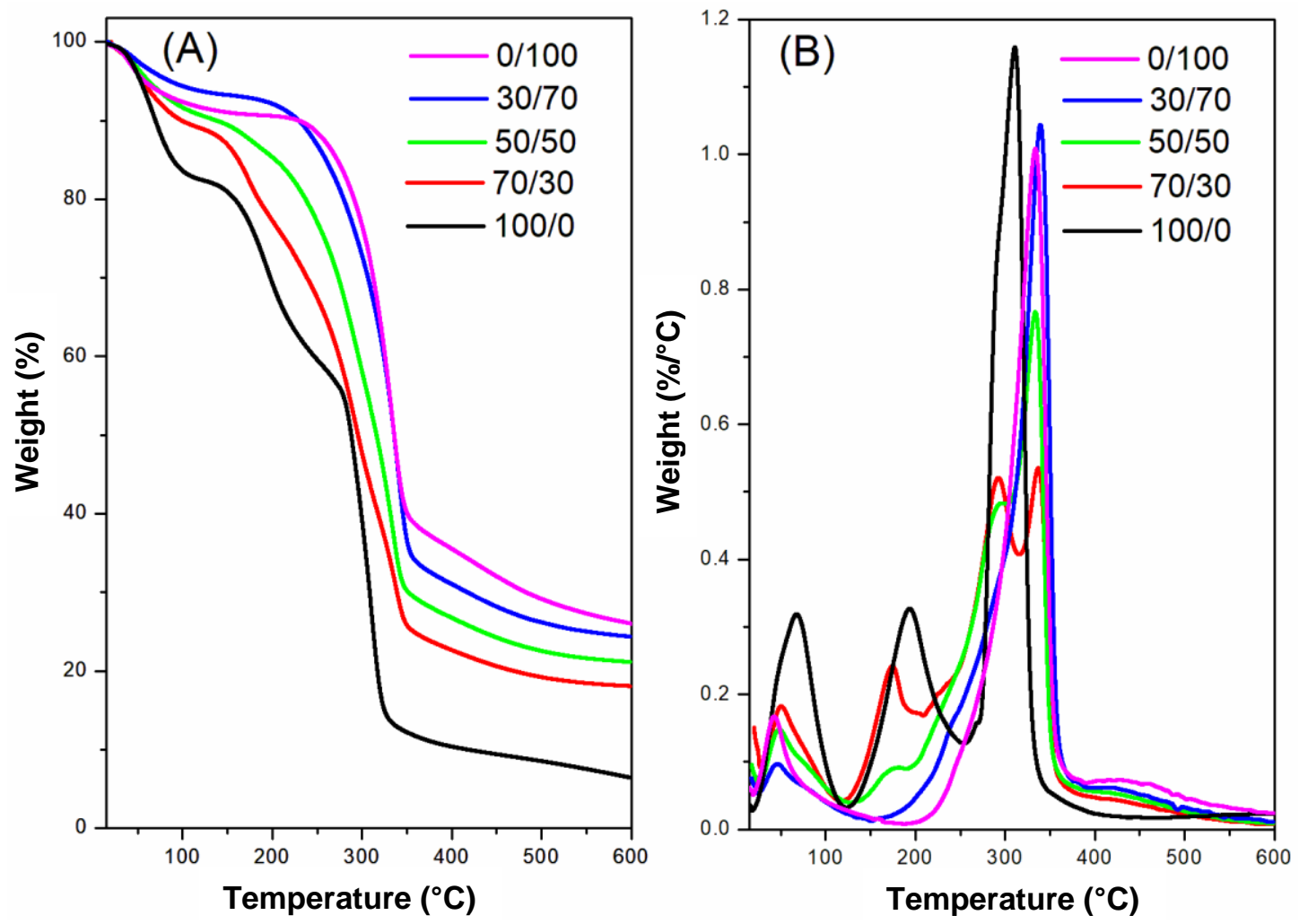

Fig. 3. Thermogravimetric analyses of pure PS (100/0), pure MFC (0/100), and PS/MFC (70/30, 50/50, and 30/70) composites ((A) TGA curves and (B) DTG curves)

The TGA curves (Fig. 3a) indicate that the pure PS was less thermally stable than pure MCF, due to the fact that PS is amorphous, whereas MCF is semicrystalline. Consequently, with increasing amounts of MFC in the composites, the thermal stability of the resulting material improved (Table 2). The films displayed two to four stages of weight loss, which were identified from the DTG peaks.

The first stage of weight loss occurs at low temperatures (less than $100{ }^{\circ} \mathrm{C}$ ), due to the evaporation of water, with all of the formulations exhibiting a peak. However, it should be noted that composites containing larger amounts of PS exhibited higher percentages of weight loss, which is likely related to their higher hydrophilicity, which is consistent with the water content results listed in Table 1. The MFC has high percentage of weight loss than the composites up to $50 \%$ of PS. This can be explained by the high surface area created in cellulose during the microfibrillation process, which can adsorb humidity. 
Glycerol degradation occurs in the second stage of weight loss $\left(120^{\circ} \mathrm{C}\right.$ to $\left.250{ }^{\circ} \mathrm{C}\right)$, which corresponds to the second peak of the DTG curves. The PS and the PS/MFC composites with less than 50\% PS exhibited weight loss in this region. The samples prepared with at least $60 \%$ MFC (less than $40 \%$ PS) did not exhibit a peak related to glycerol degradation, which was most certainly due to the lower concentration of this plasticizer in the composites, since it is added as a function of the PS content in the films.

The third stage $\left(270{ }^{\circ} \mathrm{C}\right.$ to $\left.330^{\circ} \mathrm{C}\right)$ is related to starch decomposition. Consequently, samples with higher PS content exhibited this peak, and as expected, weight loss percentages decreased as the PS content decreased. In formulations 50/50 and 30/70, the thermograms display a discreet shoulder related to starch degradation. The final weight loss occurs in the fourth stage $\left(300{ }^{\circ} \mathrm{C}\right.$ to $\left.370{ }^{\circ} \mathrm{C}\right)$, which is associated with the thermal degradation of cellulose. Samples with a higher MFC content displayed higher weight loss percentages in this region. Table 2 provides more detailed information obtained from the DTG curves.

Table 2. Degradation Stages and Residual Weights for Pure PS, pure MFC, and PS/MFC Composites. Values of Temperature Correspond to DTG Peaks

\begin{tabular}{|c|c|c|c|c|c|}
\hline \multirow{2}{*}{$\begin{array}{l}\text { PS/MFC } \\
\text { Formulation } \\
(\mathrm{g} / \mathrm{g})\end{array}$} & \multicolumn{4}{|c|}{ Temperature at DTG Peaks $\left({ }^{\circ} \mathrm{C}\right) /$ Weight Loss (\%) } & \multirow{2}{*}{$\begin{array}{l}\text { Residual } \\
\text { Weight at } \\
600^{\circ} \mathrm{C}(\%)\end{array}$} \\
\hline & First stage & Second stage & Third stage & Fourth stage & \\
\hline $100 / 0$ & 64 / 8.16 & $191 / 16.65$ & $310 / 44.10$ & --- & 6.44 \\
\hline $90 / 10$ & $51 / 6.10$ & $184 / 19.05$ & $310 / 35.07$ & --- & 14.75 \\
\hline $80 / 20$ & $57 / 6.04$ & $190 / 17.26$ & $303 / 31.49$ & $345 / 20.13$ & 14.44 \\
\hline $70 / 30$ & 48 / 3.62 & $172 / 13.64$ & $290 / 30.09$ & $336 / 21.30$ & 18.09 \\
\hline $60 / 40$ & $44 / 3.85$ & $173 / 13.11$ & $289 / 27.11$ & $338 / 22.84$ & 16.96 \\
\hline $50 / 50$ & 47 / 2.92 & $178 / 9.76$ & $290 / 24.65$ & 332 / 23.36 & 21.16 \\
\hline $40 / 60$ & $42 / 2.65$ & --- & --- & $330 / 46.98$ & 22.52 \\
\hline $30 / 70$ & $44 / 1.91$ & --- & --- & $338 / 50.57$ & 24.39 \\
\hline $20 / 80$ & 42 / 1.97 & --- & --- & $339 / 51.15$ & 24.80 \\
\hline $10 / 90$ & $41 / 1.48$ & --- & --- & $338 / 48.89$ & 24.30 \\
\hline $0 / 100$ & 47 / 3.42 & --- & --- & $336 / 47.11$ & 24.12 \\
\hline
\end{tabular}

The second and third weight loss stages are not shown in Table 2, for composites containing at least $60 \%$ MFC. There was degradation of glycerol and starch in these regions, since the composites have these components. However, these degradations appear in curves as a fourth stage peak broadening, at lower temperatures. Furthermore, the DTG temperatures for composites richer in PS displayed lower thermal stability when compared to those films richer in MFC. In general, carbonaceous residues appear at temperatures greater than $370{ }^{\circ} \mathrm{C}$. Samples containing greater amounts of cellulose resulted in higher residual weights, with a residual weight of $24 \%$ for pure MFC. It is notable that the cellulose degradation temperature did not significantly change among nearly all the composites $\left(330{ }^{\circ} \mathrm{C}\right.$ to $\left.345^{\circ} \mathrm{C}\right)$, which indicated the stability of the composite films.

The DSC curves in Fig. 4 show the events related to the PS, MFC, and PS/MFC composite formulations. The first thermal event at less than $100{ }^{\circ} \mathrm{C}$ is related to water evaporation, resulting in the weight loss identified in Fig. 3. 


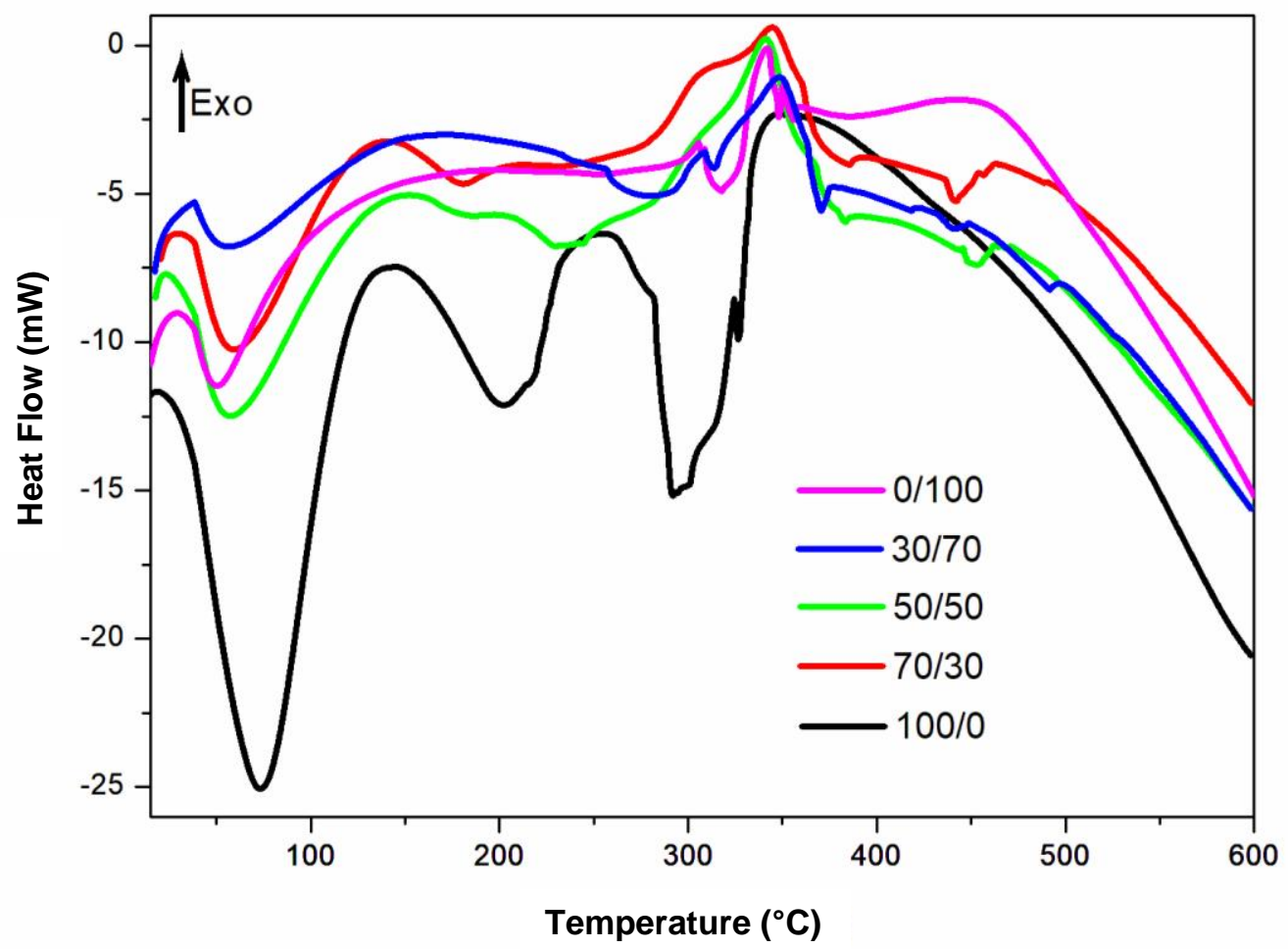

Fig. 4. The DSC curves for the pure PS (100/0), pure MFC (0/100), and PS/MFC (70/30, 50/50, and 30/70) composites

There were two more endothermic peaks related to the presence of PS; the first one at $200{ }^{\circ} \mathrm{C}$ can be attributed to glycerol degradation, and the second peak at $300{ }^{\circ} \mathrm{C}$ can be ascribed to the necessary energy to degrade starch. For the MFC, there is an endothermic shoulder at 210 and $360{ }^{\circ} \mathrm{C}$, which corresponds to the thermal degradation of the cellulose. It was noticeable that the composites and MFC did not exhibit these peaks with same intensity in comparison with the peak for PS. The insertion of MFC in the formulations decreased the intensity of the peaks, enlarging the initial peaks to shoulders, which indicated enhanced thermal stability of these materials upon the addition of MFC, decreasing the energy necessary to degrade the material.

The tensile strength, maximum strain, and Young modulus of the pure PS and MFC films, as well as the PS/MFC composites are listed in Table 3. The mechanical properties of many of the composite films are significant, and it can be concluded that the addition of MFC to the PS matrix resulted in the increased mechanical resistance of the composites.

As expected, the film of pure PS (100/0) was rather flexible, as reflected in its low Young modulus $(0.11 \mathrm{GPa})$. Regarding the Young modulus of the PS/MFC composites, increasing the MFC content resulted in an increase of the Young modulus, suggesting the formation of composites with higher rigidity. This trend was observed with MFC contents as high as $80 \%$, which exhibited a Young modulus of $4.55 \mathrm{GPa}$. Factors such as good fiber dispersion in the polymer matrix and a high aspect ratio of MFC facilitated the formation of hydrogen bonds and adhesion between the PS and MFC, which resulted in materials with improved mechanical properties. Films containing 90\% MFC exhibited a decreased Young modulus, indicating a possible collapse of the polymer-fiber network. This lower rigidity may be due to decreased polymer infusion in the fibers, since it is present at a lower 
percentages, as well as the presence of higher fiber ends in the materials, providing potential stress points in the composite (Mohanty et al. 2000). It is interesting to note that the 30/70 PS/MFC and 20/80 PS/MFC composites had Young modulus values that were similar to the pure MFC film.

Table 3. Tensile Behavior of the PS, MFC, and PS/MFC Composite Films Related to Tensile Strength, Maximum Strain, and Young Modulus

\begin{tabular}{|c|c|c|c|}
\hline $\begin{array}{c}\text { PS/MFC } \\
\text { Formulation }\end{array}$ & Tensile Strength (MPa) & Maximum Strain (\%) & $\begin{array}{c}\text { Young Modulus } \\
(\mathrm{GPa})\end{array}$ \\
\hline $100 / 0$ & $2.50 \pm 0.45^{\mathrm{a}}$ & $5.91 \pm 1.13^{\mathrm{a}, \mathrm{d}}$ & $0.11 \pm 0.01^{\mathrm{a}}$ \\
\hline $90 / 10$ & $6.28 \pm 0.43^{\mathrm{a}, \mathrm{b}}$ & $7.48 \pm 0.33^{\mathrm{b}, \mathrm{c}}$ & $0.21 \pm 0.03^{\mathrm{a}}$ \\
\hline $80 / 20$ & $7.47 \pm 0.70^{\mathrm{a}, \mathrm{b}}$ & $5.63 \pm 0.52^{\mathrm{a}, \mathrm{d}, \mathrm{f}}$ & $0.35 \pm 0.07^{\mathrm{a}}$ \\
\hline $70 / 30$ & $13.53 \pm 0.76^{\mathrm{b}, \mathrm{c}}$ & $7.61 \pm 0.43^{\mathrm{c}}$ & $0.71 \pm 0.09^{\mathrm{a}, \mathrm{b}}$ \\
\hline $60 / 40$ & $13.83 \pm 3.25^{\mathrm{b}, \mathrm{c}}$ & $6.31 \pm 1.26^{\mathrm{a}, \mathrm{b}}$ & $1.09 \pm 0.21^{\mathrm{b}}$ \\
\hline $50 / 50$ & $20.26 \pm 3.32^{\mathrm{c}, \mathrm{d}}$ & $5.20 \pm 0.89^{\mathrm{a}, \mathrm{d}, \mathrm{f}}$ & $2.10 \pm 0.34^{\mathrm{c}}$ \\
\hline $40 / 60$ & $26.21 \pm 1.91^{\mathrm{d}, \mathrm{e}}$ & $5.10 \pm 0.69^{\mathrm{d}, \mathrm{f}}$ & $2.71 \pm 0.51^{\mathrm{d}}$ \\
\hline $30 / 70$ & $33.46 \pm 7.08^{\mathrm{e}, \mathrm{f}}$ & $3.72 \pm 0.78^{\mathrm{e}, \mathrm{f}}$ & $4.92 \pm 0.43^{\mathrm{e}}$ \\
\hline $20 / 80$ & $51.47 \pm 2.22^{\mathrm{g}, \mathrm{h}}$ & $4.47 \pm 0.51^{\mathrm{f}}$ & $4.55 \pm 1.08^{\mathrm{e}}$ \\
\hline $10 / 90$ & $61.66 \pm 21.79^{\mathrm{g}}$ & $6.72 \pm 0.59^{\mathrm{a}, \mathrm{b}, \mathrm{c}}$ & $2.60 \pm 1.13^{\mathrm{c}, \mathrm{d}}$ \\
\hline $0 / 100$ & $45.10 \pm 5.59^{\mathrm{f}, \mathrm{h}}$ & $1.92 \pm 0.22^{\mathrm{g}}$ & $5.76 \pm 2.07^{\mathrm{e}}$ \\
\hline $\begin{array}{l}\text { Note: The values followed by the same letter are statistically equivalent at a } p \text {-value less than } \\
0.05 \text { (Tukey's test) }\end{array}$ & \multicolumn{4}{|l}{} \\
\hline
\end{tabular}

An increased MFC content in the PS/MFC composites resulted in increased tensile strength (as shown in Table 3). The 10/90 composite exhibited a tensile strength of 61.7 $\mathrm{MPa}$, which was notably higher than that of the pure MFC film (45.1 MPa), and 25 times higher than pure PS film (2.5 MPa), thus demonstrating the reinforcing effect of MFC when added to PS to form PS/MFC composite films. The least amount of strain was observed in the 30/70, 20/80, and 0/100 (pure MFC) formulations, which was in agreement with the Young modulus values that indicated a higher rigidity of these formulations. All the samples containing PS presented higher elongation, when compared to the pure MFC film, which indicated that the addition of PS could improve the MFC tenacity. These results suggested that efficient stress transference occurs between PS and MFC at the interface, especially for formulations prepared with up to $80 \%$ MFC.

\section{CONCLUSIONS}

1. Starch, cellulose, and glycerol are bioresources used for the fabrication of renewable films. Starch adheres to cellulose, and the different plasticized starch/microfibrillated cellulose (PS/MFC) composite film formulations exhibited different properties when compared to pure PS and MFC films.

2. A larger amount of MFC present in the PS/MFC composite films tended to result in lower water content and higher opacity.

3. The PS/MFC composite films displayed higher thermal stability than pure PS films. Composite compositions with a MFC content greater than $60 \%$ resulted in more thermally stable materials. 
4. Microfibrillated cellulose acts as a reinforcing filler for PS in the PS/MFC composite films. The addition of MFC to the PS matrix confers mechanical resistance to the composite formulations.

5. The PS/MFC films display potential for packing applications. Specific properties of gas permeability, water, and solvent resistance should be evaluated depending on the content and environmental conditions of use.

\section{ACKNOWLEDGMENTS}

The authors are grateful for the financial support from FINEP (DendePalm Project - Estratégias Genômicas e Agregação de Valor para a Cadeia Produtiva do Dendê - SEG 12.15.00.007.00.00). In addition, V. C. T. is thankful for a fellowship from the CNPq.

\section{REFERENCES CITED}

Abbott, A. P., Abolibda, T. Z., Davis, S. J., Emmerling, F., Lourdin, D., Leroy, E., and Wise, W. R. (2014). "Glycol based plasticisers for salt modified starch," RSC Advances 4(76), 40421-40427. DOI: 10.1039/c4ra06220e

ASTM D638-02 (2002). "Standard test method for tensile properties of plastics," ASTM International, West Conshohocken, PA.

ASTM D644-99 (2007). "Standard test method for moisture content of paper and paperboard by oven drying," ASTM International, West Conshohocken, PA.

Chen, G.-Q., and Jiang, X.-R. (2018). "Next generation industrial biotechnology based on extremophilic bacteria," Current Opinion in Biotechnology 50, 94-100. DOI: 10.1016/j.copbio.2017.11.016

Cheng, G., Zhou, M., Wei, Y.-J., Cheng, F., and Zhu, P.-X. (2019). “Comparison of mechanical reinforcement effects of cellulose nanocrystal, cellulose nanofiber, and microfibrillated cellulose in starch composites," Polymer Composites 40(S1), 365372. DOI: $10.1002 / \mathrm{pc} .24685$

de Campos, A., de Sena Neto, A. R., Rodrigues, V. B., Luchesi, B. R., Moreira, F. K. V., Correa, A. C., Mattoso, L. H. C., and Marconcini, J. M. (2017). "Bionanocomposites produced from cassava starch and oil palm mesocarp cellulose nanowhiskers," Carbohydrate Polymers 175, 330-336. DOI: 10.1016/j.carbpol.2017.07.080

Fahma, F., Iwamoto, S., Hori, N., Iwata, T., and Takemura, A. (2010). "Isolation, preparation, and characterization of nanofibers from oil palm empty-fruit-bunch (OPEFB)," Cellulose 17(5), 977-985. DOI: 10.1007/s10570-010-9436-4

Fiorote, J. A., Freire, A. P., de Sousa Rodrigues, D., Martins, M. A., Andreani, L., and Valadares, L. F. (2019). "Preparation of composites from natural rubber and oil palm empty fruit bunch cellulose: Effect of cellulose morphology on properties," BioResources 14(2), 3168-3181. DOI: 10.15376/biores.14.2.3168-3181

Hiltunen, S., Heiskanen, I., and Backfolk, K. (2018). "Effect of hydrothermal treatment of microfibrillated cellulose on rheological properties and formation of hydrolysis products," Cellulose 25(8), 4653-4662. DOI: 10.1007/s10570-018-1884-2 
HunterLab (1996). "Applications note: CIE L* a*b* color scale," (https://www.hunterlab.se/wp-content/uploads/2012/11/CIE-L-a-b-.pdf), Accessed 25 September 2020.

HunterLab (2008). “Applications note: Opacity,” (https://support.hunterlab.com/hc/enus/article_attachments/201360299/an02_97.pdf), Accessed 25 September 2020.

Ilyas, R. A., Sapuan, S. M., Atiqah, A., Ibrahim, R., Abral, H., Ishak, M. R., Zainudin, E. S., Nurazzi N. M., Atikah, M. S. N., Ansari, M. N. M., et al. (2019). "Sugar palm (Arenga pinnata [Wurmb.] Merr) starch films containing sugar palm nanofibrillated cellulose as reinforcement: Water barrier properties," Polymer Composites 41(2), 459-467. DOI:10.1002/pc. 25379

Ilyas, R. A., Sapuan, S. M., Ishak, M. R., and Zainudin, E. S. (2018). "Development and characterization of sugar palm nanocrystalline cellulose reinforced sugar palm starch bionanocomposites," Carbohydrate Polymers 202, 186-202. DOI:

10.1016/j.carbpol.2018.09.002

Iwamoto, S., Abe, K., and Yano, H. (2008). "The effect of hemicelluloses on wood pulp nanofibrillation and nanofiber network characteristics," Biomacromolecules $9(3)$, 1022-1026. DOI: 10.1021/bm701157n

Karim, A. A., Norziah, M. H., and Seow, C. C. (2000). "Methods for the study of starch retrogradation," Food Chemistry 71(1), 9-36. DOI: 10.1016/S0308-8146(00)00130-8

Lavoine, N., Desloges, I., Dufresne, A., and Bras, J. (2012). "Microfibrillated cellulose Its barrier properties and applications in cellulosic materials: A review," Carbohydrate Polymers 90(2), 735-764. DOI: 10.1016/j.carbpol.2012.05.026

Lengowski, E. C., Bonfatti Júnior, E. A., Simon, L., de Muñiz, G. I. B., de Andrade, A. S., Nisgoski, S., and Klock, U. (2020). "Different degree of fibrillation: Strategy to reduce permeability in nanocellulose-starch films," Cellulose 27, 10855-10872. DOI: $10.1007 / \mathrm{s} 10570-020-03232-4$

Li, M., Tian, X., Jin, R., and Li, D. (2018). "Preparation and characterization of nanocomposite films containing starch and cellulose nanofibers," Industrial Crops and Products 123, 654-660. DOI: 10.1016/j.indcrop.2018.07.043

Liu, D., Dong, Y., Bhattacharyya, D., and Sui, G. (2017). "Novel sandwiched structures in starch/cellulose nanowhiskers (CNWs) composite films," Composites Communications 4, 5-9. DOI: 10.1016/j.coco.2017.03.001

Liu, D., Zhong, T., Chang, P. R., Li, K., and Wu, Q. (2010). "Starch composites reinforced by bamboo cellulosic crystals," Bioresource Technology 101(7), 25292536. DOI: 10.1016/j.biortech.2009.11.058

Mathlouthi, M. (2001). "Water content, water activity, water structure and the stability of foodstuffs," Food Control 12(7), 409-417. DOI: 10.1016/S0956-7135(01)00032-9

Mohanty, A. K., Khan, M. A., and Hinrichsen, G. (2000). "Surface modification of jute and its influence on performance of biodegradable jute-fabric/Biopol composites," Composite Science and Technology 60(7), 1115-1124. DOI: 10.1016/S02663538(00)00012-9

Müller, C. M. O., Yamashita, F., and Laurindo, J. B. (2008). "Evaluation of the effects of glycerol and sorbitol concentration and water activity on the water barrier properties of cassava starch films through a solubility approach," Carbohydrate Polymers 72(1), 82-87. DOI: 10.1016/j.carbpol.2007.07.026

Ramlee, N. A., Jawaid, M., Zainudin, E. S., and Yamani, S. A. K. (2019). “Tensile, physical and morphological properties of oil palm empty fruit bunch/sugarcane bagasse fibre reinforced phenolic hybrid composites," Journal of Materials Research 
and Technology 8(4), 3466-3474. DOI: 10.1016/j.jmrt.2019.06.016

Schmitt, H., Guidez, A., Prashantha, K., Soulestin, J., Lacrampe, M. F., and Krawczak, P. (2015). "Studies on the effect of storage time and plasticizers on the structural variations in thermoplastic starch," Carbohydrate Polymers 115, 364-372. DOI: 10.1016/j.carbpol.2014.09.004

Tozluoglu, A., Fidan, H., Tutus, A., Arslan, R., Sertkaya, S., Poyraz, B., Kucuk, S. D., Sozbir, T., Yemsen, B., and Gucus, M. O. (2021). "Reinforcement potential of modified nanofibrillated cellulose in recycled paper production," BioResources 16(1), 911-941. DOI: 10.15376/biores.16.1.911-941

Veiga-Santos, P., Oliveira, L. M., Cereda, M. P., Alves, A. J., and Scamparini, A. R. P. (2005). "Mechanical properties, hydrophilicity and water activity of starch-gum films: Effect of additives and deacetylated xanthan gum," Food Hydrocolloids 19(2), 341-349. DOI: 10.1016/j.foodhyd.2004.07.006

Yoshida, H., Hatakeyama, T., and Hatakeyama, H. (1993). "Characterization of water in polysaccharide hydrogels by DSC," Journal of Thermal Analysis 40(2), 483-489. DOI:10.1007/bf02546617

Article submitted: September 15, 2020; Peer review completed: October 31, 2020; Revised version received and accepted: March 19, 2021; Published: April 5, 2021. DOI: 10.15376/biores.16.2.3746-3759 